\title{
Messenger RNA expression of COX-2 and angiogenic factors in primary colorectal cancer and corresponding liver metastasis
}

\author{
HIROTOSHI KOBAYASHI ${ }^{1,2}$, KENICHI SUGIHARA ${ }^{1}$, HIROYUKI UETAKE $^{1}$, TETSURO HIGUCHI ${ }^{1}$, \\ MASAMICHI YASUNO ${ }^{1}$, MASAYUKI ENOMOTO ${ }^{1}$, SATORU IIDA ${ }^{1}$, HEINZ-JOSEF LENZ ${ }^{3}$, \\ KATHLEEN D. DANENBERG ${ }^{4}$ and PETER V. DANENBERG ${ }^{2}$ \\ ${ }^{1}$ Department of Surgical Oncology, Graduate School, Tokyo Medical and Dental University, Tokyo, Japan; \\ Departments of ${ }^{2}$ Biochemistry and Molecular Biology and ${ }^{3}$ Medical Oncology, University of Southern \\ California/Norris Comprehensive Cancer Center; ${ }^{4}$ Response Genetics, Inc., Los Angeles, CA, USA
}

Received December 5, 2008; Accepted January 29, 2009

DOI: 10.3892/ijo_00000243

\begin{abstract}
Several new drugs that are targeted towards various angiogenic factors have shown considerable potential for controlling tumor proliferation and metastases. Expression levels of the targeted genes in primary tumors and metastases should be understood to maximize the use of such drugs. The present study aimed to clarify associations between mRNA levels of cyclooxygenase $2(\mathrm{COX}-2)$ and angiogenic factors [vascular endothelial growth factor (VEGF) and interleukin-8 (IL-8)] in primary colorectal cancer and in corresponding liver metastasis. We also compared these gene expressions of primary colorectal cancer between patients with and without liver metastasis. In 31 pairs of formalin-fixed and paraffinembedded primary and metastatic liver tumors as well as 27 specimens of consecutive stage II patients without recurrence, mRNA was quantified by real-time reverse transcriptionpolymerase chain reaction following the laser capture microdissection. We found a significantly positive correlation in $I L-8$ between primary tumors and matched liver metastases $\left(\mathrm{p}=0.034, \mathrm{r}_{\mathrm{s}}=0.39\right)$ and in VEGF $(\mathrm{p}=0.0083$, $\mathrm{r}_{\mathrm{s}}=0.48$ ), but not in $C O X-2$, which was associated with both $V E G F\left(\mathrm{p}=0.044, \mathrm{r}_{\mathrm{s}}=0.37\right)$ and $I L-8\left(\mathrm{p}=0.0004, \mathrm{r}_{\mathrm{s}}=0.64\right)$ in primary colorectal cancers. Multiple regression analysis revealed that $C O X-2$ was independently associated with $I L-8$ $(\mathrm{p}<0.0001)$. There were no differences in mRNA levels between patients with and without liver metastasis. The mRNA levels of VEGF and IL-8 in liver metastasis can be
\end{abstract}

Correspondence to: Dr Hirotoshi Kobayashi, Department of Surgical Oncology, Tokyo Medical and Dental University, 1-5-45 Yushima, Bunkyo-ku, Tokyo, Japan

E-mail: h-kobayashi.srg2@tmd.ac.jp

Key words: colon cancer, liver metastasis, cyclooxygenase-2, vascular endothelial growth factor, interleukin-8, reverse transcription-polymerase chain reaction, messenger RNA predicted from those in primary colorectal cancer. COX-2 might exert angiogenic activity more through the IL-8, than the VEGF pathway. These angiogenic factors were sufficiently up-regulated before hematogenous metastasis. These preliminary data merit further validation studies.

\section{Introduction}

Colorectal cancer is a worldwide leading cause of cancer death $(1,2)$. The most promising treatment for patients with colorectal cancer is curative resection, but this is sometimes impossible. Some patients with colorectal cancer constantly relapse despite curative resection (3). Molecular targeting therapy has recently been developed for advanced colorectal cancer. Various drugs targeting anti-angiogenesis have improved the survival of patients with metastatic colorectal cancer (4), because angiogenesis is essential for tumor growth (5).

Interleukin-8 (IL-8) is a pro-inflammatory chemotactic cytokine that stimulates the migration of cells including neutrophils, monocytes, lymphocytes, and fibroblasts (6-9). The angiogenic activity of IL-8 produced by monocytes and macrophages was originally demonstrated in 1992 (10). Several investigators have reported that IL-8 is also secreted by some human colorectal cancer cells. Studies have shown that the range of IL-8 expression is $45-74 \%$ in colorectal cancer $(11,12)$. However, details of IL-8 messenger RNA (mRNA) expression in colorectal cancer and corresponding liver metastasis remain unclear.

Senger et al originally identified the vascular endothelial growth factor (VEGF), which promotes angiogenesis, in 1983 (13). Bevacizumab is a monoclonal antibody to VEGF that has improved the survival of patients with metastatic colorectal cancer when combined with other chemotherapies (4).

Cyclooxygenase (COX) is a key enzyme that is involved in the conversion of arachidonic acid to prostaglandins. The COX-2 isoform is expressed in most organs, but can be up-regulated by various factors including cytokines, growth factors and tumor promoters $(14,15)$. Recent studies have demonstrated that COX-2 inhibitors exert angiogenic effects 
in colorectal cancer $(16,17)$. However, the association of mRNA between COX-2 and angiogenic factors in colorectal cancer remain unclear.

Several novel drugs that are targeted towards various angiogenic factors have shown considerable potential for controlling tumor proliferation and metastasis. To maximize the effects of such drugs, correlations between expression levels of targeted genes in primary tumors and metastases should be determined. The present study examines associations between the mRNA levels of COX-2 and angiogenic factors such as VEGF and IL-8 in primary colorectal cancer and in corresponding liver metastasis. We also evaluated the association between COX-2 and angiogenic factors

\section{Patients and methods}

Patients. We enrolled 31 patients who had undergone surgical resection for both primary colorectal cancer and liver metastasis between April 1997 and June 2005 at Tokyo Medical and Dental University Hospital. Of these, 18 and 13 had metachronous and synchronous liver metastases, respectively. The median time from primary resection to hepatectomy was 20 months. We compared mRNA expression between primary colorectal cancer and corresponding liver metastases. We also enrolled 27 patients who had undergone curative resection for stage II colorectal cancer between January 1998 and August 2001 and who had not relapsed during a median follow-up of $4.8 \pm 1.1$ years. We then compared mRNA expression between the 31 patients with liver metastasis (Group 1) and the 27 stage II patients without relapse (Group 2). Patients with ulcerative colitis, Crohn's disease, or familial adenomatous polyposis were excluded from this study, which was approved by the institutional review board of Tokyo Medical and Dental University, and all patients provided written, informed consent to participate. None of the patients had undergone prior radiotherapy or chemotherapy. Table I summarizes their clinical and histopathological data.

Laser capture microdissection. Formalin-fixed paraffinembedded tumor tissue blocks were cut into $10-\mu \mathrm{m}$-thick slices, stained with nuclear fast red (American MasterTech Scientific, Lodi, CA) and then laser capture microdissection (P.A.L.M. Microlaser Technologies AG, Munich, Germany) was applied. This technique allows only tumor cells to be examined with stromal tissues removed.

RNA isolation and cDNA synthesis. After laser capture microdissection, RNA was isolated according to the proprietary procedure of Response Genetics (US patent no. 6,248,535) and then cDNA was prepared from each sample as described (18).

Quantitative reverse transcription polymerase chain reaction $(R T-P C R)$. Genes of interest and an internal reference gene (B-actin) were quantified using fluorescence-based real-time TaqMan detection (ABI PRISM 7900 Sequence Detection System; Applied Biosystems, Foster City, CA) as described (19) and the specific mRNA amplification primers and probes were listed in Table II. The PCR mixture comprised
Table I. Clinicopathological characteristics.

\begin{tabular}{|c|c|c|c|}
\hline & $\begin{array}{c}\text { Group } 1 \\
\quad(\mathrm{n}=31 \\
\text { with liver } \\
\text { metastasis })\end{array}$ & $\begin{array}{c}\text { Group } 2 \\
\text { (27 stage II } \\
\text { without } \\
\text { relapse) }\end{array}$ & P-value \\
\hline Age (years) & $61 \pm 9$ & $69 \pm 11$ & 0.0035 \\
\hline \multicolumn{4}{|l|}{ Gender } \\
\hline Male & 24 & 15 & NS \\
\hline Female & 7 & 12 & \\
\hline \multicolumn{4}{|l|}{ Primary site } \\
\hline Cecum & 1 & 0 & NS \\
\hline Ascending colon & 3 & 4 & \\
\hline Transverse colon & 3 & 5 & \\
\hline Descending colon & 2 & 1 & \\
\hline Sigmoid colon & 9 & 9 & \\
\hline Rectosigmoid & 9 & 4 & \\
\hline Rectum & 4 & 4 & \\
\hline \multicolumn{4}{|l|}{$\begin{array}{l}\text { Pathology } \\
\text { (differentiation) }\end{array}$} \\
\hline Well & 12 & 11 & NS \\
\hline Moderate & 17 & 15 & \\
\hline Poor & 1 & 1 & \\
\hline Mucinous type & 1 & 0 & \\
\hline \multicolumn{4}{|l|}{ Depth of tumor } \\
\hline $\mathrm{T} 1$ & 0 & 0 & $\mathrm{NS}$ \\
\hline $\mathrm{T} 2$ & 2 & 0 & \\
\hline $\mathrm{T} 3$ & 21 & 25 & \\
\hline $\mathrm{T} 4$ & 8 & 2 & \\
\hline
\end{tabular}

Lymph node metastasis

$\begin{array}{lrr}\text { N0 } & 9 & 27 \\ \text { N1 } & 13 & 0 \\ \text { N2 } & 9 & 0\end{array}$

$<0.0001$

Lymphatic invasion

$\begin{array}{lrr}\text { Absent } & 4 & 8 \\ \text { Minimal } & 13 & 17 \\ \text { Moderate } & 12 & 2 \\ \text { Severe } & 2 & 0\end{array}$

0.013

Venous invasion

\begin{tabular}{lrrr} 
Absent & 0 & 5 & NS \\
Minimal & 13 & 11 & \\
Moderate & 11 & 8 & \\
Severe & 7 & 3 & \\
\hline
\end{tabular}

$1,200 \mathrm{nmol} / 1$ of each primer, $200 \mathrm{nmol} / 1$ probe, $0.4 \mathrm{U}$ of AmpliTaq Gold Polymerase, $200 \mathrm{nmol} / \mathrm{l}$ each of dATP, 
Table II. Primer and probe sequences of analyzed genes.

Sequences

COX-2

Forward primer

Reverse primer

Probe

IL-8

Forward primer

Reverse primer

Probe

VEGF

Forward primer

Reverse primer

Probe

B-actin

Forward primer

Reverse primer

Probe
5'-GCTCAAACATGATGTTTGCATTC-3'

5'-GCTGGCCCTCGCTTATGA-3'

5'-(FAM)TGCCCAGCACTTCACGCATCAGTT(TAMRA)-3'

\author{
5'-CAGCTCTGTGTGAAGGTGCAGTT-3' \\ 5'-GGGTGGAAAGGTTTGGAGTATGTC-3' \\ 5'-(FAM)TGCACTGACATCTAAGTTCTTTAGCACTCCTTGGC(TAMRA)-3'
}

\author{
5'-AGTGGTCCCAGGCTGCAC-3' \\ 5'-TCCATGAACTTCACCACTTCGT-3' \\ 5'-(FAM)ATGGCAGAAGGAGGAGGGCAGAATCA(TAMRA)-3'
}

dCTP, dGTP, dTTP, $3.5 \mathrm{mmol} / 1 \mathrm{MgCl}_{2}$, and 1X TaqMan buffer A containing a reference dye in a final volume of $20 \mu 1$ (all reagents were supplied by Perkin-Elmer Applied Biosystems). The cycling conditions comprised $50^{\circ} \mathrm{C}$ for $2 \mathrm{~min}$ and $95^{\circ} \mathrm{C}$ for $10 \mathrm{~min}$ followed by 46 cycles at $95^{\circ} \mathrm{C}$ for $15 \mathrm{sec}$ and $60^{\circ} \mathrm{C}$ for $1 \mathrm{~min}$. Gene expression is expressed as ratios (relative mRNA levels) between genes of interest and the internal reference $B$-actin gene. All samples were amplified in triplicate.

Statistical analysis. Data were statistically analyzed using the StatView statistical package (StatView 5.0, Abacus Concepts, Inc., Berkeley, CA, USA). All data are expressed as median \pm standard deviation. We compared the mRNA levels of genes of interest between primary colorectal cancer and corresponding liver metastasis using the Wilcoxon's signedrank test. Spearman's rank correlation analysis determined correlations between mRNA levels of primary tumor and liver metastases and associations between mRNA levels of COX-2 and angiogenic factors. Associations between clinicopathological features and mRNA expression were assessed by the Mann-Whitney $U$ test with two variables and by the Kruskal-Wallis test with three or more variables. Statistical significance was established at $\mathrm{p}<0.05$ for all values.

\section{Results}

Table I shows the clinicopathological features of the patients. Those with stage II colorectal cancer whose cancer did not recur were older than those with liver metastasis $(\mathrm{p}=0.0035)$. The extent of lymph node metastasis and lymphatic invasion significantly differed between the two groups $(\mathrm{p}<0.0001$ and $\mathrm{p}=0.013$, respectively). The mRNA levels of each gene did not differ between patients with primary colorectal cancer accompanied by synchronous or metachronous liver metastasis (Fig. 1A). The mRNA levels of primary tumors also did not significantly differ between patients with solitary or multiple liver metastases (Fig. 1B).

Correlation in mRNA expression between primary colorectal cancer and corresponding liver metastasis. The expression of COX-2 mRNA did not significantly differ between primary colorectal cancer and corresponding liver metastasis from 31 patients (Group 1; Fig. 2A). On the other hand, VEGF values were significantly associated between primary tumor and matched liver metastasis (Fig. 2B; $\mathrm{p}=0.0083, \mathrm{r}_{\mathrm{s}}=0.482$ ) and IL-8 (Fig. 2C, p=0.034, $r_{s}=0.39$ ).

Correlation in $m R N A$ expression between COX-2 and angiogenic factors in primary colorectal cancer. The mRNA expression of COX-2 significantly correlated with that of VEGF in primary tumors from Group 1 patients (Fig. 3A; $\mathrm{p}=0.044, \mathrm{r}_{\mathrm{s}}=0.37$ ) and IL-8 (Fig. 3B; $\mathrm{p}=0.0004, \mathrm{r}_{\mathrm{s}}=0.64$ ). Multivariate analysis revealed that IL- 8 mRNA and COX-2 mRNA expression was independently associated (Table III; $\mathrm{p}<0.0001)$.

Comparison of mRNA levels between patients with stage II colorectal cancer without recurrence and those with colorectal cancer with liver metastasis. The mRNA levels of primary tumors in Group 1 and 2 patients were as follows: COX-2, $0.61 \pm 0.55$ and $0.59 \pm 0.78 ;$ IL-8, $6.17 \pm 7.68$ and $6.27 \pm 13.43$ 
A

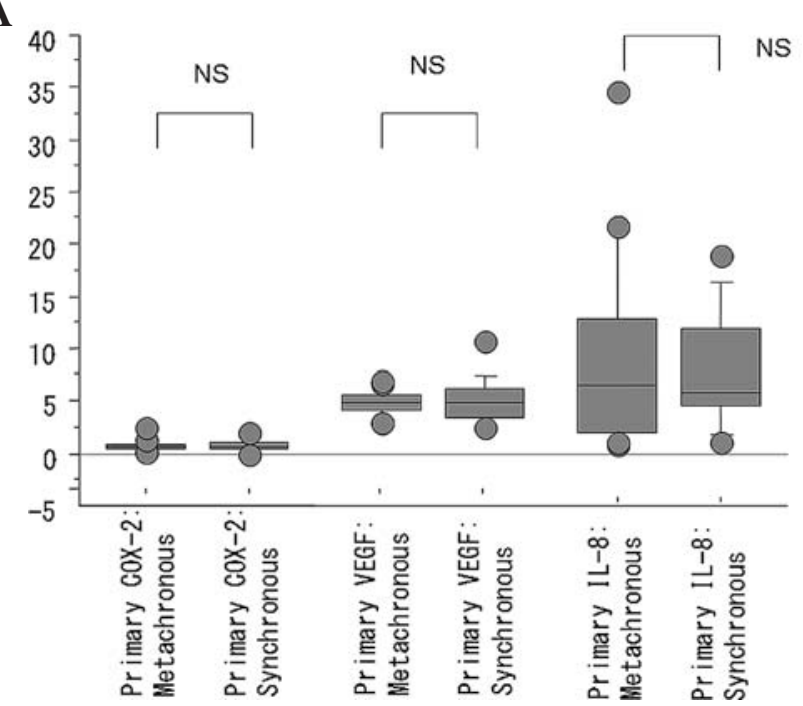

B

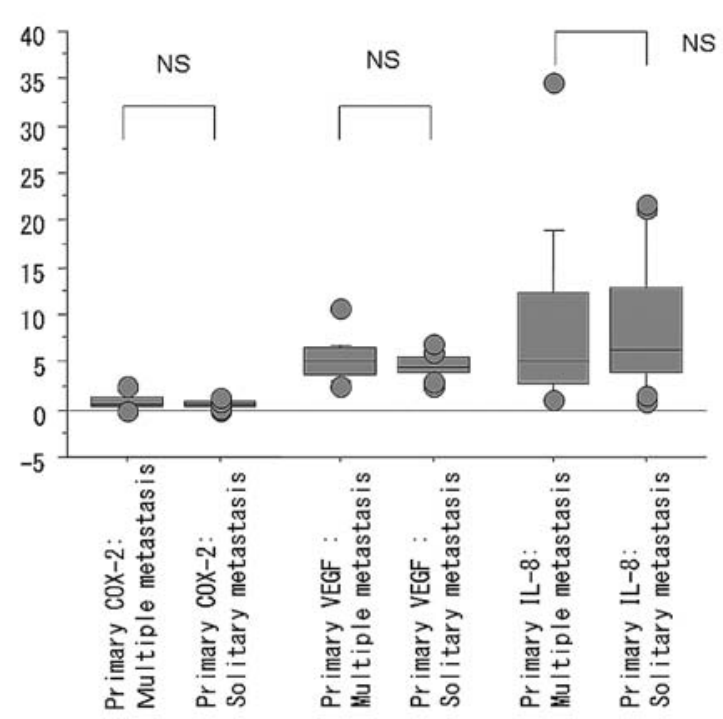

Figure 1. Messenger RNA expression in primary colorectal tumor of patients with liver metastasis according to: (A), timing of metastasis; and (B), number of metastatic tumors.

A
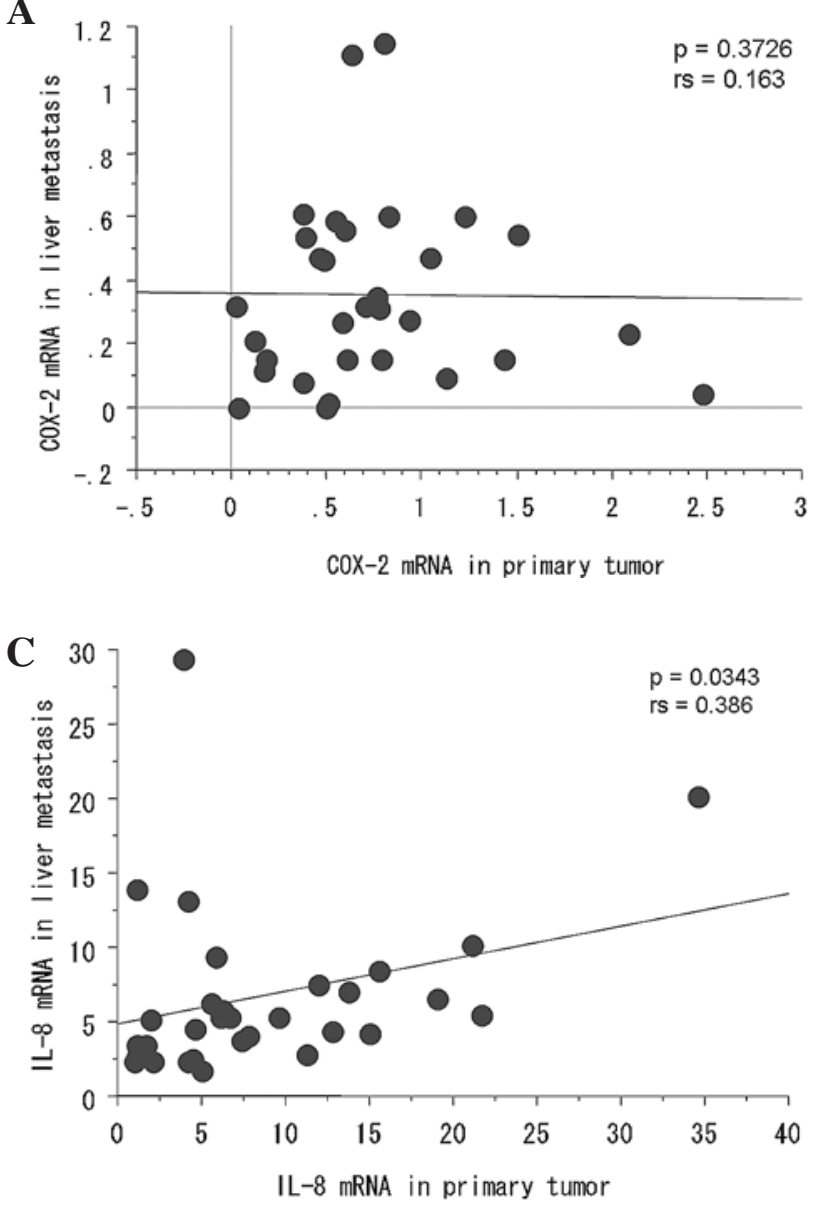

Figure 2. Correlation of messenger RNA expression between primary colorectal cancer and corresponding liver metastasis. (A), COX-2; (B), VEGF; and (C), IL-8.

and VEGF, 4.87 \pm 1.64 and 5.50 \pm 4.50 , respectively. The COX-2 $(\mathrm{p}=0.55$; Fig. 4A), IL-8 $(\mathrm{p}=0.61$; Fig. 4B $)$ and VEGF
B

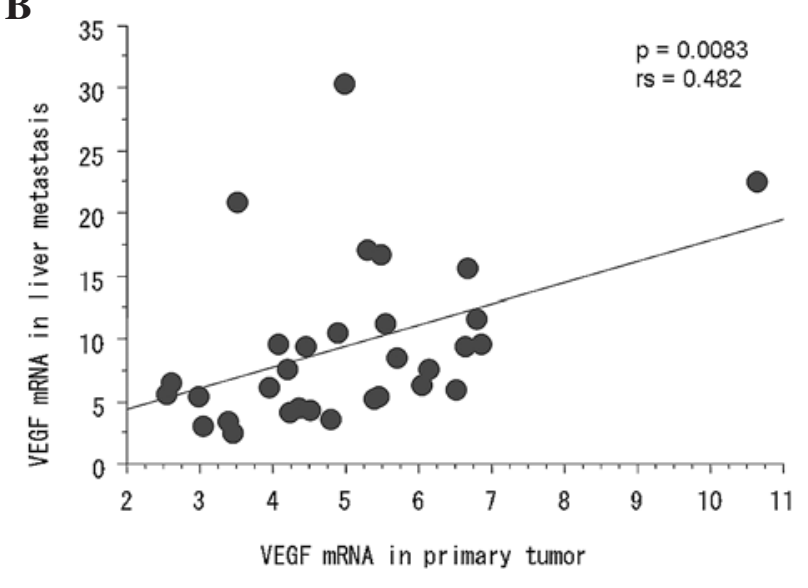

Table III. Multiple regression analysis between COX-2 and angiogenic factors.

\begin{tabular}{lc}
\hline & \multicolumn{1}{c}{ P-value } \\
\cline { 2 - 2 } Gene & Multiple regression analysis \\
\hline COX-2, VEGF & 0.14 \\
COX-2, IL-8 & $<0.0001$ \\
\hline
\end{tabular}

$(\mathrm{p}=0.22$; Fig. 4C) mRNA levels did not differ between Groups 1 and 2 .

\section{Discussion}

The present study demonstrated positive correlations between mRNA levels of IL-8 and VEGF, but not of COX-2 in primary 

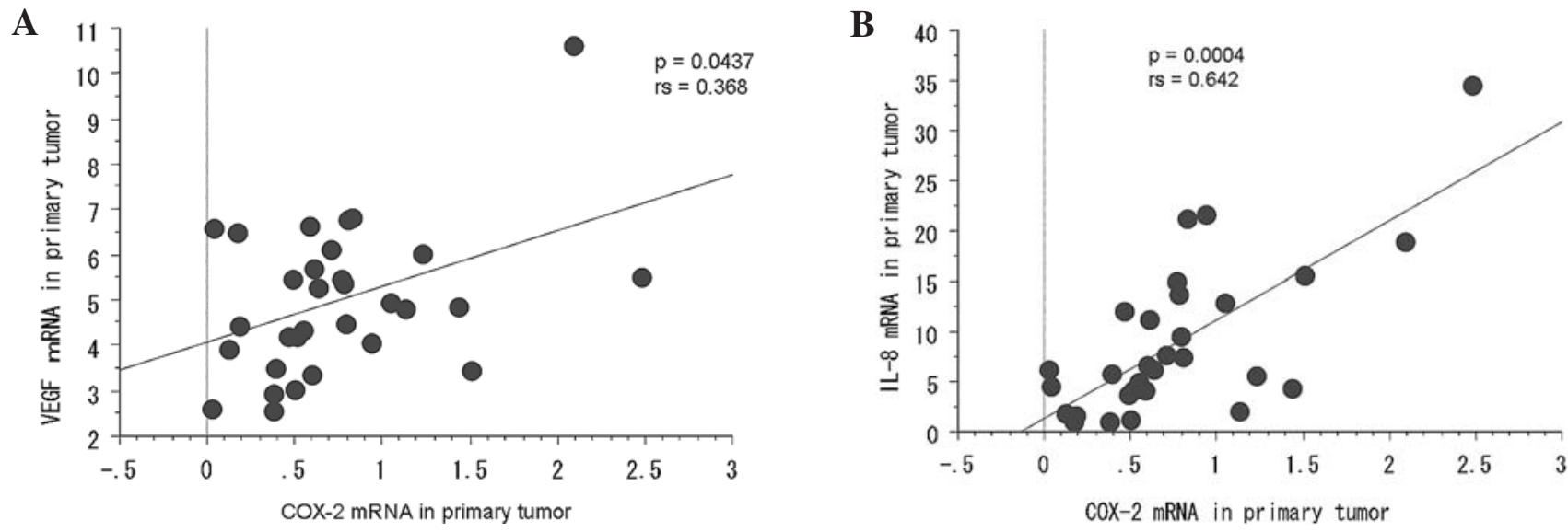

Figure 3. Correlation of messenger RNA expression between COX-2 and: (A), VEGF; or (B), IL-8 in primary tumors.

A

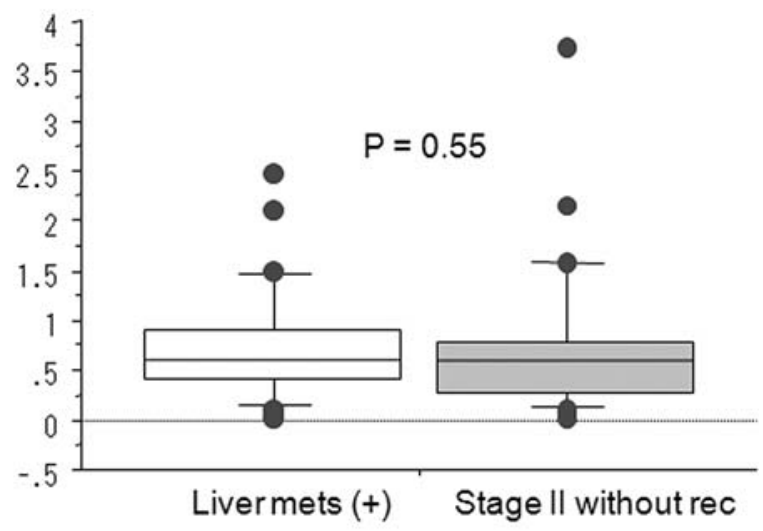

C

IL-8 in primary colorectal cancer

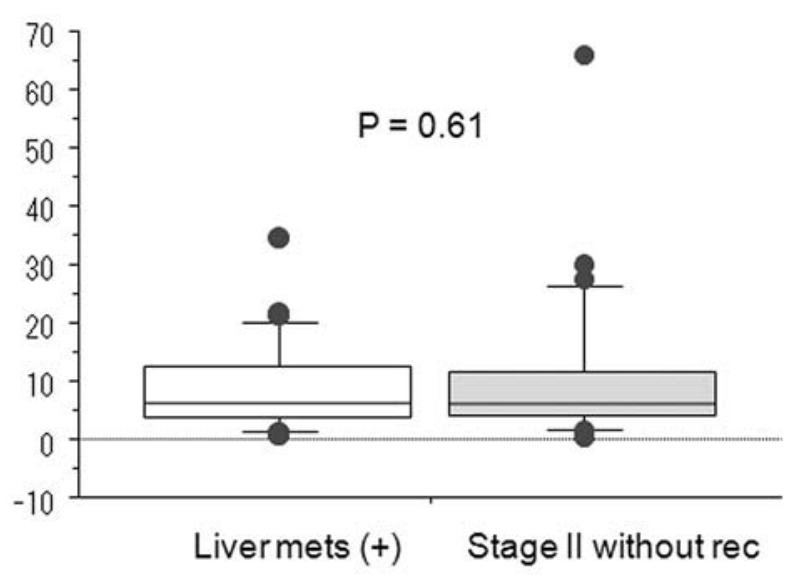

Figure 4. Comparison of messenger RNA expression between primary colorectal cancer with liver metastasis and stage II tumor without recurrence. (A), COX-2; (B), VEGF; and (C), IL-8.

colorectal cancer and corresponding liver metastases. The expression of COX-2 in primary colorectal cancer and liver metastasis has not been examined in detail. Only one immunohistochemical study has compared COX-2 expression
B

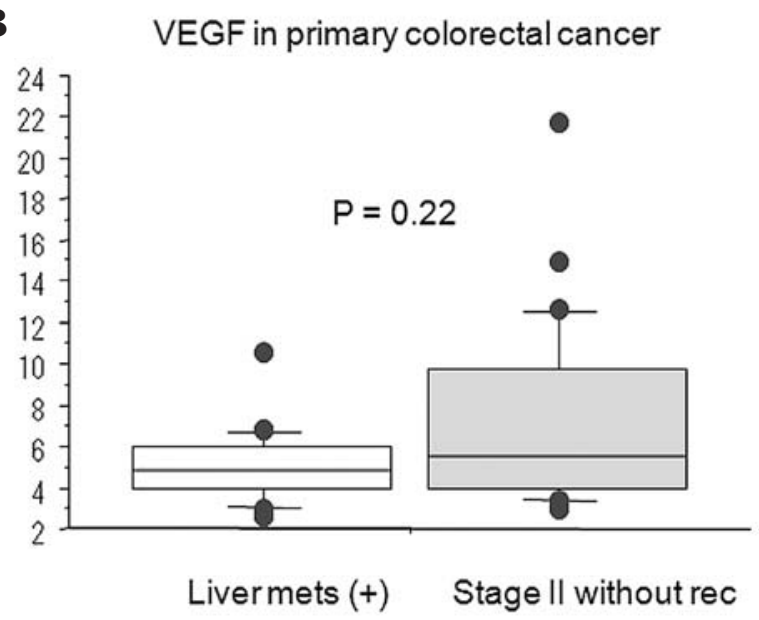

in primary colorectal cancer and matched liver metastasis (20). That study found that immunostaining scores of COX-2 positively correlated between primary colorectal cancer and corresponding liver metastasis. Our results contradict these findings, perhaps because they semi-quantified COX-2 protein expression whereas we quantified COX-2 mRNA levels. However, another explanation could be that COX-2 mRNA expression is more dependent on the surrounding environment under conditions of liver metastasis. Further study is required to clarify this issue. Kuramochi et al found a positive correlation in VEGF mRNA expression between primary colorectal cancer and matched liver metastasis (21). Our results support these findings.

Correlations in IL-8 mRNA levels between primary colorectal cancer and corresponding liver metastasis have not been reported. Rubie et al reported that IL- 8 mRNA and protein expression is up-regulated in colorectal cancer compared with adjacent normal tissues (22). Anti-angiogenic therapy for colorectal cancer targeting IL-8 might be developed soon, and the present results should be applicable at that time.

Multiple regression analysis revealed a significant correlation between mRNA levels of IL-8 and of COX-2 in advanced colorectal cancer. To our knowledge, the association 
between COX-2 and IL-8 mRNA expression in colorectal cancer has not yet been reported. However, details of interactions between COX-2 and IL- 8 were not clarified in the present study. Singh et al reported that COX-2 expression led to IL-8 induction in breast cancer cells (23). A similar mechanism might exist in colorectal cancer, because we found a close correlation between the mRNA levels of COX-2 and IL-8. Details of the mechanism between COX-2 and IL- 8 in colorectal cancer require further investigation using various strategies.

Since Tsujii et al reported that COX-2 regulates angiogenesis in colon cancer cells (24), several studies have shown an association between COX-2 expression and angiogenesis $(16,17)$. However, our univariate analysis found that COX-2 mRNA expression in primary colorectal cancer positively correlated with VEGF mRNA levels, whereas multivariate analysis did not. One reason for this finding might be that several factors other than COX-2 affect VEGF and thus, angiogenesis.

The present study found no differences among COX-2, VEGF, and IL-8 mRNA levels in primary colorectal cancer between patients with synchronous and metachronous liver metastases. The mRNA levels of each factor did not differ between primary tumors from patients with solitary liver or multiple liver metastases, suggesting that these genes are already sufficiently up-regulated by the time liver metastases develop from colorectal cancer. Therefore, the mRNA levels of these genes might not change with further tumor advances.

We found no difference in the IL- 8 mRNA levels between TNM stage II and IV primary colorectal cancer. There were no differences in the COX-2 and VEGF mRNA levels between two groups, either. These findings suggest that the IL-8 as well as COX-2 and VEGF mRNA levels in colorectal cancer are already sufficiently up-regulated at stage II. Antiangiogenic therapy targeting these genes may exert their effect for patients with stage II colorectal cancer as well as for those with stage IV. To maximally exclude bias, we examined samples from consecutive patients with stage II cancer who had not developed recurrence for at least 3 years. Terada et al reported that the IL-8 levels were lower in T1, than in T2-4 colorectal cancer (25). Therefore, IL- 8 might become upregulated early. They found higher IL- 8 levels in patients with, than without liver metastases. One explanation for the difference in the results between their study and ours might be that they measured IL-8 levels using an ELISA in only 9 patients with liver metastasis. Further large-scale investigations are required to clarify this issue.

In conclusion, the present study found no association between mRNA expression of angiogenic factors and liver metastasis. The mRNA expression of these angiogenic factors in colorectal cancer might already be sufficiently up-regulated before hematogenous metastasis. The angiogenic activity of COX-2 might be exerted more through the IL- 8 than the VEGF pathway. The mRNA levels of VEGF and IL- 8 in liver metastasis can be predicted from those in primary colorectal cancer. These findings will be useful when considering anti-angiogenic therapy for patients with colorectal cancer, although further studies are required to validate these preliminary data.

\section{Acknowledgments}

We thank Yoko Takagi for her excellent technical assistance. Part of this study was presented at the annual AACR meeting, San Diego, April 12-16, 2008.

\section{References}

1. Jemal A, Siegel R, Ward E, Hao Y, Xu J, Murray T and Thun MJ: Cancer statistics, 2008. CA Cancer J Clin 58: 71-96, 2008.

2. Muto T, Kotake K and Koyama Y: Colorectal cancer statistics in Japan: data from JSCCR registration, 1974-1993. Int J Clin Oncol 6: 171-176, 2001

3. Kobayashi H, Mochizuki H, Sugihara K, Morita T, Kotake K, Teramoto T, Kameoka S, Saito Y, Takahashi K, Hase K, Oya M, Maeda K, Hirai T, Kameyama M, Shirouzu K and Muto T: Characteristics of recurrence and surveillance tools after curative resection for colorectal cancer: a multicenter study. Surgery 141: 67-75, 2007

4. Hurwitz H, Fehrenbacher L, Novotny W, Cartwright T, Hainsworth J, Heim W, Berlin J, Baron A, Griffing S, Holmgren E, Ferrara N, Fyfe G, Rogers B, Ross R and Kabbinavar F: Bevacizumab plus irinotecan, fluorouracil, and leucovorin for metastatic colorectal cancer. N Engl J Med 350: 2335-2342, 2004

5. Folkman J: Endothelial cells and angiogenic growth factors in cancer growth and metastasis. Introduction. Cancer Metastasis Rev 9: 171-174, 1990.

6. Baggiolini M, Dewald B and Moser B: Human chemokines: an update. Annu Rev Immunol 15: 675-705, 1997.

7. Matsushima K and Oppenheim JJ: Interleukin-8 and MCAF: novel inflammatory cytokines inducible by IL 1 and TNF. Cytokine 1: 2-13, 1989.

8. Oppenheim JJ, Zachariae CO, Mukaida N and Matsushima K: Properties of the novel proinflammatory supergene 'intercrine' cytokine family. Annu Rev Immunol 9: 617-648, 1991.

9. Rossi D and Zlotnik A: The biology of chemokines and their receptors. Annu Rev Immunol 18: 217-242, 2000.

10. Koch AE, Polverini PJ, Kunkel SL, Harlow LA, DiPietro LA, Elner VM, Elner SG and Strieter RM: Interleukin-8 as a macrophage-derived mediator of angiogenesis. Science 258: 1798-1801, 1992.

11. Brew R, Southern SA, Flanagan BF, McDicken IW and Christmas SE: Detection of interleukin-8 mRNA and protein in human colorectal carcinoma cells. Eur J Cancer 32A: 2142-2147, 1996.

12. Fox SH, Whalen GF, Sanders MM, Burleson JA, Jennings K, Kurtzman S and Kreutzer D: Angiogenesis in normal tissue adjacent to colon cancer. J Surg Oncol 69: 230-234, 1998.

13. Senger DR, Galli SJ, Dvorak AM, Perruzzi CA, Harvey VS and Dvorak HF: Tumor cells secrete a vascular permeability factor that promotes accumulation of ascites fluid. Science 219: 983-985, 1983.

14. Jones DA, Carlton DP, McIntyre TM, Zimmerman GA and Prescott S: Molecular cloning of human prostaglandin endoperoxide synthase type II and demonstration of expression in response to cytokines. J Biol Chem 268: 9049-9054, 1993.

15. Williams CS and DuBois RN: Prostaglandin endoperoxide synthase: why two isoforms? Am J Physiol 270: G393-G400, 1996.

16. Kobayashi H, Gonda T, Uetake H, Higuchi T, Enomoto M and Sugihara K: JTE-522, a selective COX-2 inhibitor, interferes with the growth of lung metastases from colorectal cancer in rats due to inhibition of neovascularization: a vascular cast model study. Int J Cancer 112: 920-926, 2004.

17. Masferrer JL, Leahy KM, Koki AT, Zweifel BS, Settle SL, Woerner BM, Edwards DA, Flickinger AG, Moore RJ and Seibert K: Antiangiogenic and antitumor activities of cyclooxygenase-2 inhibitors. Cancer Res 60: 1306-1311, 2000.

18. Lord RV, Salonga D, Danenberg KD, Peters JH, DeMeester TR, Park JM, Johansson J, Skinner KA, Chandrasoma P, DeMeester SR, Bremner CG, Tsai PI and Danenberg PV: Telomerase reverse transcriptase expression is increased early in the Barrett's metaplasia, dysplasia, adenocarcinoma sequence. J Gastrointest Surg 4: 135-142, 2000.

19. Gibson UE, Heid CA and Williams PM: A novel method for real-time quantitative RT-PCR. Genome Res 6: 995-1001, 1996. 
20. Nakamoto RH, Uetake H, Iida S, Kolev YV, Soumaoro LT, Takagi Y, Yasuno M and Sugihara K: Correlations between cyclooxygenase-2 expression and angiogenic factors in primary tumors and liver metastases in colorectal cancer. Jpn J Clin Oncol 37: 679-685, 2007.

21. Kuramochi H, Hayashi K, Uchida K, Miyakura S, Shimizu D, Vallbohmer D, Park S, Danenberg KD, Takasaki K and Danenberg PV: Vascular endothelial growth factor messenger RNA expression level is preserved in liver metastases compared with corresponding primary colorectal cancer. Clin Cancer Res 12: 29-33, 2006

22. Rubie C, Frick VO, Pfeil S, Wagner M, Kollmar O, Kopp B, Graber S, Rau BM and Schilling MK: Correlation of IL-8 with induction, progression and metastatic potential of colorectal cancer. World J Gastroenterol 13: 4996-5002, 2007.
23. Singh B, Berry JA, Vincent LE and Lucci A: Involvement of IL-8 in COX-2-mediated bone metastases from breast cancer. J Surg Res 134: 44-51, 2006.

24. Tsujii M, Kawano S, Tsuji S, Sawaoka H, Hori M and DuBois RN: Cyclooxygenase regulates angiogenesis induced by colon cancer cells. Cell 93: 705-716, 1998 .

25. Terada H, Urano $\mathrm{T}$ and Konno H: Association of interleukin-8 and plasminogen activator system in the progression of colorectal cancer. Eur Surg Res 37: 166-172, 2005. 